\title{
CIDADE SAUDÁVEL: \\ Estratégias para intervenções na frente d'água do Centro Expandido Continental do Recife, Brasil.
}

\author{
Barretto, Natália \\ (Arquiteta e Urbanista pela Universidade Católica de Pernambuco) nataliaclb@outlook.com \\ Camara, Andrea \\ (Arquiteta e Urbanista pela Universidade Federal de Pernambuco e Doutora pela Universidade Politécnica \\ da Catalunha) andrea.camara@unicap.br
}

\section{RESUMO}

A presente pesquisa investiga relações entre a qualidade do espaço urbano e a saúde pública, ou seja, como o espaço urbano pode influenciar a nossa saúde (física ou mental). O seu objetivo desenvolve-se a partir do entendimento da potencialidade de espaços públicos em contato com elementos e paisagens naturais e como estes espaços tornam-se oportunos para o aumento dos índices positivos de saúde pública. Afim de propor diretrizes e estratégias para a melhoria destes espaços, realizou-se o estudo da qualidade dos espaços públicos existentes na frente d'água do rio Capibaribe, no Centro Expandido Continental da cidade do Recife, Brasil. A pesquisa reuniu diagnóstico do território e estudo de estratégias associadas ao conceito norteador, a saúde urbana.

Palavras chave: saúde urbana, espaços públicos, bem estar, cidades.

Linha de investigação: espaço público e projeto urbano na metrópole contemporânea.

\section{ABSTRACT}

The present research investigates relations between the quality of urban space and public health, that is, how urban space can influence our health (physical or mental). Its purpose is to understand the potential of public spaces in contact with natural elements and landscapes and how these spaces become opportune for the increase of positive public health indexes. In order to propose guidelines and strategies for the improvement of these spaces, a study was carried out on the quality of public spaces on the water front of the Capibaribe River, in the Continental Expanded Center of the city of Recife, Brazil. The research gathered a diagnosis of the territory and study of strategies associated to the guiding concept, urban health.

Keywords: urban health, public spaces, well-being, cities.

Topic: public space and urban design in the contemporary metropolis. 


\section{Introdução:}

Em constante desenvolvimento, as cidades promovem interações, proporcionam memórias, incentivam atividades, articulam caminhos e provocam reações ao ambiente construído. Segundo relatório da Organização das Nações Unidas (ONU, 2016), 54\% da população mundial vive em cidades e uma das pautas mais atuais para urbanistas do mundo todo é a questão da densidade populacional e habitacional e o que estas representam para a qualidade do espaço urbano. É um desafio que vem sendo lidado em diferentes escalas ao redor do mundo e conforme Farr (2013:5), "as características desagradáveis dos espaços abertos de hoje são especialmente danosas em ambientes urbanos densos, chegando a fazer com que as pessoas evitem ficar na rua, reforçando a tendência de permanecerem do lado de dentro, com as janelas fechadas."

O entendimento de que os espaços urbanos afetam os níveis da saúde pública, podendo ser responsáveis pela produção da boa ou da má saúde, é uma prioridade mundialmente reconhecida em 2010 pela Organização Mundial de Saúde (OMS) (Rydin et al., 2012). Diante dessa problemática, a disciplina do urbanismo interage com a saúde pública em várias escalas. Desde o planejamento e desenho urbano à usabilidade do espaço, questões ligadas à infraestrutura, à qualidade de espaços públicos e à mobilidade ratificam a importância desta investigação. Ao associar urbanismo com saúde, Lefebvre (1968:49) assume que "o urbanismo saberia discernir os espaços doentes dos espaços ligados à saúde mental e social, geradores dessa saúde. Médicos do espaço, ele teria a capacidade de conceber um espaço harmonioso, normal e normalizante".

O conceito da saúde urbana refere-se ao estudo da saúde de populações urbanas, considerando que as características das cidades afetam nossa saúde física e mental, (Galea; Vlahov, 2005) as quais, segundo Kaplan e Kaplan (1989), estão associadas a experiências promovidas pela paisagem natural e pela proporção de espaços verdes nas cidades. Portanto, os espaços públicos abertos podem interferir na qualidade de vida, afetando diretamente questões da saúde pública. Doenças provocadas pelo estilo de vida como estresse, diabetes e doenças cardíacas, afetaram mais e mais pessoas na segunda metade do século 20, tornando relevante estudar como e para onde nos movemos, e talvez ainda mais crucial, por que não nos movemos no nosso dia-a-dia. (Gehl, 2013:101). Paisagens naturais são elementos positivos para o bem-estar, e segundo Olmstead, os espaços naturais "empregam e exercitam a mente sem a sensação de cansaço; tranquilizam e animam, e assim, através da influência da mente sobre o corpo, promovem efeitos de refrescância e revigoração para todo o sistema". (Kaplan, 1995). Da mesma forma, McHarg (1971), acreditava que o planejamento urbano deve levar em consideração os processos ecológicos e que estes implicam em uma sociedade com mais oportunidades e maior qualidade de vida, além de valorizar as qualidades reais dos espaços físicos.

Segundo a OMS (2006), "a saúde é um estado de completo bem-estar físico, mental e social e não apenas a ausência de doença ou enfermidade", ou seja, a saúde não limita-se à existência ou não de doenças, mas engloba o bem - estar, que está diretamente associado ao estilo de vida, o qual, por sua vez, está ligado à qualidade das cidades onde vivemos e das atividades por elas promovidas. O processo de urbanização pode e deve ser beneficial à saúde, no entanto, quando não acompanhada devidamente, a rápida expansão territorial e crescimento populacional podem causar riscos à saúde da população urbana. A poluição do ar, o congestionamento de veículos, a falta de segurança e a falta de áreas verdes contribuem para o aumento das taxas de mortalidade por AVC, doenças cardíacas, câncer, doenças respiratórias, lesões e doenças mentais. Como afirma Leite (2012:40), "as cidades nunca abrigaram tantas pessoas, e essa intensa urbanização acarreta o aumento do consumo de seus recursos naturais, como água e energia, e o aumento da poluição gerada." 
Nesta perspectiva, é necessário buscar o equilíbrio entre o crescimento populacional, a rápida urbanização das cidades, a utilização consciente dos recursos naturais e como tudo isso afeta a qualidade de vida humana. Como gerar qualidade de vida em ambientes urbanos? Como as cidades podem utilizar seus recursos naturais para potencializar a saúde pública? Quais estratégias urbanísticas podem ser utilizadas para tornar cidades mais saudáveis? A presente pesquisa tem como objetivo o entendimento deste panorama e a busca de respostas para estas indagações.

Apoiada nas justificativas de que os espaços verdes e a paisagem natural possuem funções fundamentais para a promoção da boa saúde, a pesquisa teve como principal foco o estudo de uma área de frente d'água, uma vez que os elementos e recursos naturais das cidades devem ser os catalizadores de um ordenamento territorial sustentável. A cidade do Recife, localizada no estado de Pernambuco, no nordeste do Brasil, foi tomada como caso de estudo, pois é banhada pelas águas dos rios Capibaribe e Beberibe, que desempenham papel fundamental na formação de sua paisagem e do processo evolutivo da cidade. No entanto, o crescimento acelerado e a falta de um planejamento urbano focado na escala humana e ambiental, levaram ao esquecimento e abandono dos rios, que por muito tempo influenciaram a vida dos recifenses. Hoje, o rio Capibaribe, por exemplo, apresenta altos níveis de poluição e de forma contrastante, não interage com a vida urbana da cidade da qual ele banha.

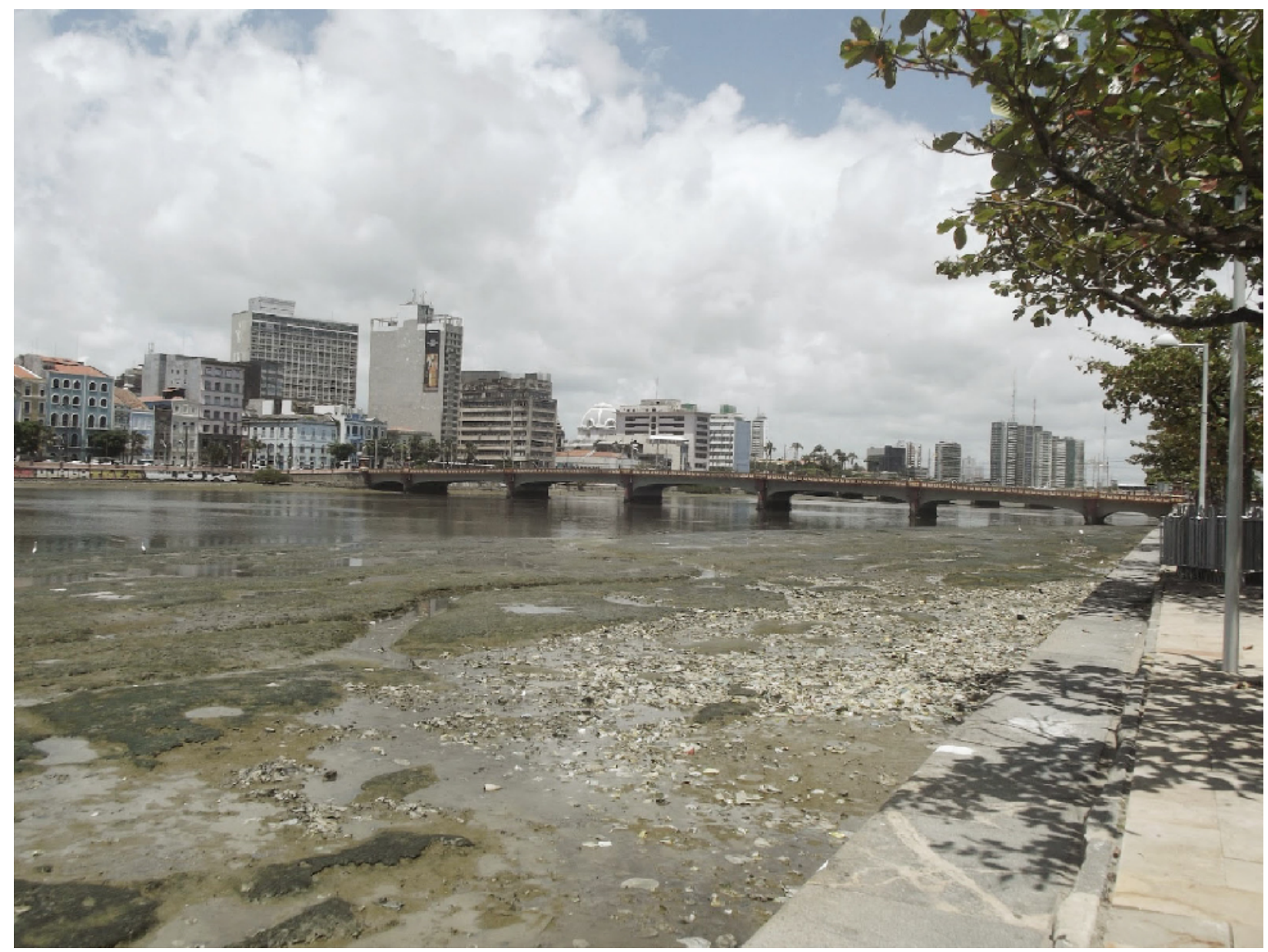

Fig. 1 Poluição no rio Capibaribe. Fonte: http://www.mamf.com.br/2016/05/rio-capibaribe-e-o-7-mais-poluido-do.html\#axzz4yMuDfZJU. Consulta: 30/10/2017. 


\section{Procedimentos metodológicos:}

Para desenvolvimento da pesquisa e obtenção de resultados e respostas aos objetivos traçados, a presente pesquisa desenvolveu-se a partir das seguintes etapas: (1) estudo de bibliografias acerca da saúde urbana a fim de entender as relações entre a qualidade do espaço urbano e os atributos necessários para uma cidade afetar positivamente a saúde de sua população; (2) realização do diagnóstico urbano aplicado ao território em estudo, levando em consideração as características mais importantes para o estudo; (3) elaboração de diretrizes e estratégias de desenho urbano com foco na área em estudo, mas que permanecem universais para o alcance de cidades saudáveis.

\section{Atributos para uma cidade saudável:}

As chamadas doenças não transmissíveis (DNT), englobam as doenças cardíacas e respiratórias, câncer, transtornos mentais e diabetes. Este grupo de doenças que partilham de quadros distintos possuem em comum o fato de estarem relacionados ao estilo de vida, podendo estar atreladas à alimentação não saudável, à falta de atividades físicas ou sedentarismo, ao isolamento social, depressão, entre outros. Estas doenças, estão entre as principais causas de morte no mundo, culminando, no ano de 2008, um total de 36 milhões de mortes. Apenas a depressão representa $4,3 \%$ da carga global de doenças e está entre as maiores causas de incapacidade em todo o mundo (OMS, 2013).

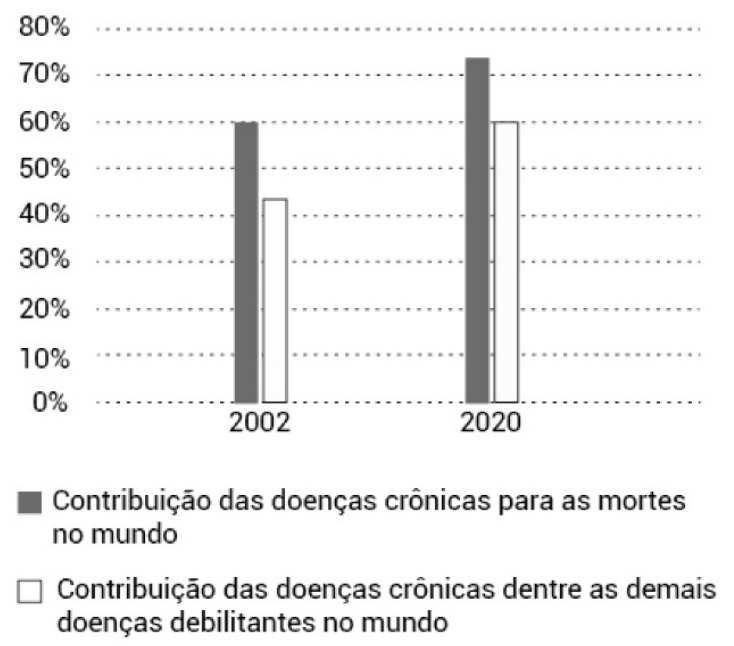

Fig. 2 Contribuição das doenças crônicas para índices de mortalidade. Elaboração própria a partir de dados do Relatório da OMS, 2002.

A OMS enfatiza que espaços verdes em áreas urbanas auxiliam na redução dos níveis de estresse, ajudando na prevenção deste grupo doenças e mais do que a mera presença destes espaços, deve também ser levada em consideração essencialmente a qualidade destes. Portanto, a relação de proximidade entre os espaços verdes e a saúde humana é fundamental. Segundo Roe et al. (2011), caminhar em determinados espaços urbanos como centros históricos e áreas verdes na cidade, incentivam a prática de atividade física e o bemestar em pessoas com problemas de saúde mental. 
Abraham et al., (2009) aborda três dimensões da saúde: o bem-estar mental, o bem-estar físico e o bem-estar social. Os autores mostram como cada um destes podem ser promovidos através da paisagem e de espaços públicos. Ao bem-estar mental, estão associadas as experiências promovidas pela paisagem natural e espaços verdes, os quais, segundo Kaplan e Kaplan (1989), agem como restauradores da atenção cognitiva, estabelecendo poderes restaurativos para a mente, atraindo a atenção das pessoas sem causar exaustão, permitindo novas descobertas e gerando curiosidades sobre o ambiente natural. O bem-estar físico está associado ao incentivo às atividades físicas. A mobilidade urbana, no geral, está relacionada a essa dimensão. Ciclofaixas, ruas pedestrianizadas e fachadas ativas ajudam a promover uma melhor caminhablidade em espaços urbanos, incentivando um deslocamento seguro e saudável. O bem-estar social, relaciona-se ao espaço urbano como estruturador de relações, da interação social entre os habitantes. Espaços públicos abertos como parques promovem contato social, troca de experiências, construção de senso de lugar e promovem maior segurança para a área.

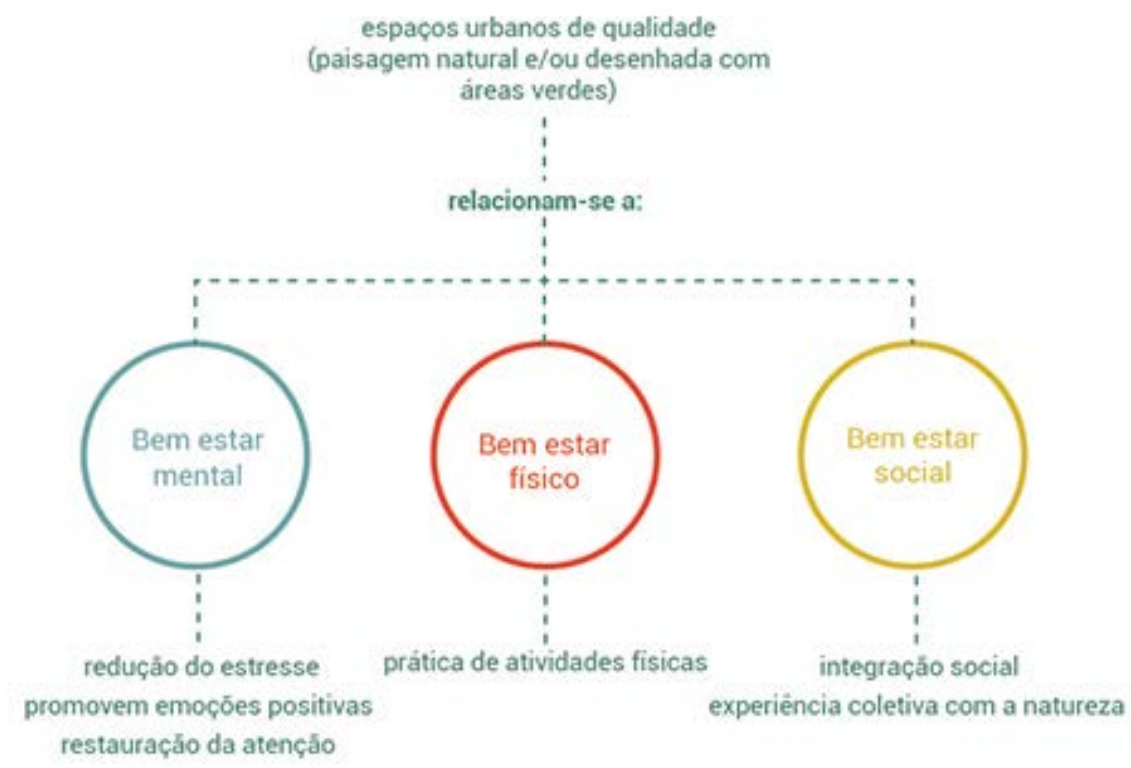

Fig. 3 Níveis de bem-estar no espaço urbano. Elaboração própria a partir de dados obtidos em Abraham et all. (2009:62)

Após compreensão acerca da saúde urbana e dos atributos necessários para uma cidade saudável, foram elaboradas "ambições". Estas, representam o fundamental para obtenção de cada um dos níveis de bem-estar em ambientes urbanos. As ambições auxiliam a formular as estratégias de desenho urbano, apresentadas ao fim da pesquisa.

Ao bem-estar mental, foram traçadas ambições relacionadas ao contato entre o indivíduo e a paisagem natural. São elas: (1) a vegetação como restauradora mental; (2) incentivar o contato humano com elementos naturais; (3) promover relações com o elemento da água; (4) transformar áreas em destinos para descanso; (5) melhorar a paisagem natural e urbana existente. Ao bem-estar físico, foram traçadas ambições relacionadas com o melhoramento de acessos e passeios e o incentivo à prática de atividades físicas. São elas: (1) melhorar acessos para pedestres; (2) incentivar o aumento do uso de bicicleta; (3) incentivar a prática de atividades de lazer; (4) incentivar práticas de atividades esportivas; (5) conforto para o pedestre; (6) melhorar integração entre as bordas d'água; (7) proibir estacionamento de veículos em margens d'água. Ao bem-estar social, as ambições relacionam-se à integração incentivo à diferentes atividades que gerem relações sociais. São elas: (1) incentivo à diferentes atividades e uso do espaço; (2) integrar todas as faixas etárias; (3) gerar atratividade para o espaço público; (4) segurança no espaço público; (5) promover atividades que incentivam relações 
sociais entre a comunidade. Desta forma, a pesquisa tomou como ponto de partida a abordagem destes três níveis de bem-estar, a fim de, ao final do diagnóstico urbano, apresentar e identificar estratégias de desenho urbano universais para a melhoria do território aqui estudado.

\section{A frente d'água do Centro Expandido Continental da cidade do Recife:}

Atualmente, cidades do mundo todo, têm focado em potencializar seus elementos naturais e utilizá-los como fonte para a qualidade de espaços públicos. Dentre elas, Chicago (EUA), Rhôdes (FR) e Madrid (ES), fizeram um ótimo trabalho ao olhar para sua malha hidrográfica de outra forma, requalificando suas margens d'água e as transformando em espaços públicos saudáveis. Em seu processo de urbanização, a cidade do Recife passou a negligenciar este elemento natural que outrora já foi tão importante para o processo de evolução da cidade, o rio. A frente d'água do Centro Expandido Continental da cidade do Recife margeia os bairros da llha do Leite até o bairro de Santo Amaro, e ainda que tenha passado por algumas transformações ao longo do tempo, a margem do rio apresenta um mau estado de conservação, com insuficiente iluminação noturna, guarda-corpos deteriorados, precariedades em áreas de lazer, entre outros. Contudo, mesmo com a falta de infraestrutura, a frente d'água mantém-se ativa, graças à grandes equipamentos e algumas habitações existentes no território.

A análise urbana realizada nesta pesquisa, buscou avaliar diferentes níveis da infraestrutura e qualidade dos espaços existentes, bem como a opinião da população que transita, trabalha e mora na área. Primeiro, realizouse um estudo do contexto histórico, que auxiliou na compreensão da importância deste território para a cidade. Depois, um estudo do contexto atual, suportado pela elaboração de mapas e levantamento de dados. Também foram realizadas aplicações de questionários com a população local, que serviu de base para entender as necessidades e os desejos para o território.

Atualmente, o rio Capibaribe e toda a sua frente d'água não apresenta bons espaços público, com poluição em suas águas e margens sem reconhecimento de seu valor histórico, paisagístico, articulador e ambiental. Os cais, que constituem espaços lineares que margeiam o rio, já apresentaram papel fundamental para a cidade, porém, ao contrário do que permite o seu potencial, hoje, não apresentam tratamentos paisagísticos e áreas de lazer e permanência que os tornem espaços atrativos. Assim, a frente d'água, ao invés de contribuir para a paisagem urbana e para a saúde pública, acaba por contribuir para a degradação ambiental, já que as águas do rio, a vegetação ribeirinha e as frentes d'água são sujas, degradadas e abandonadas. 


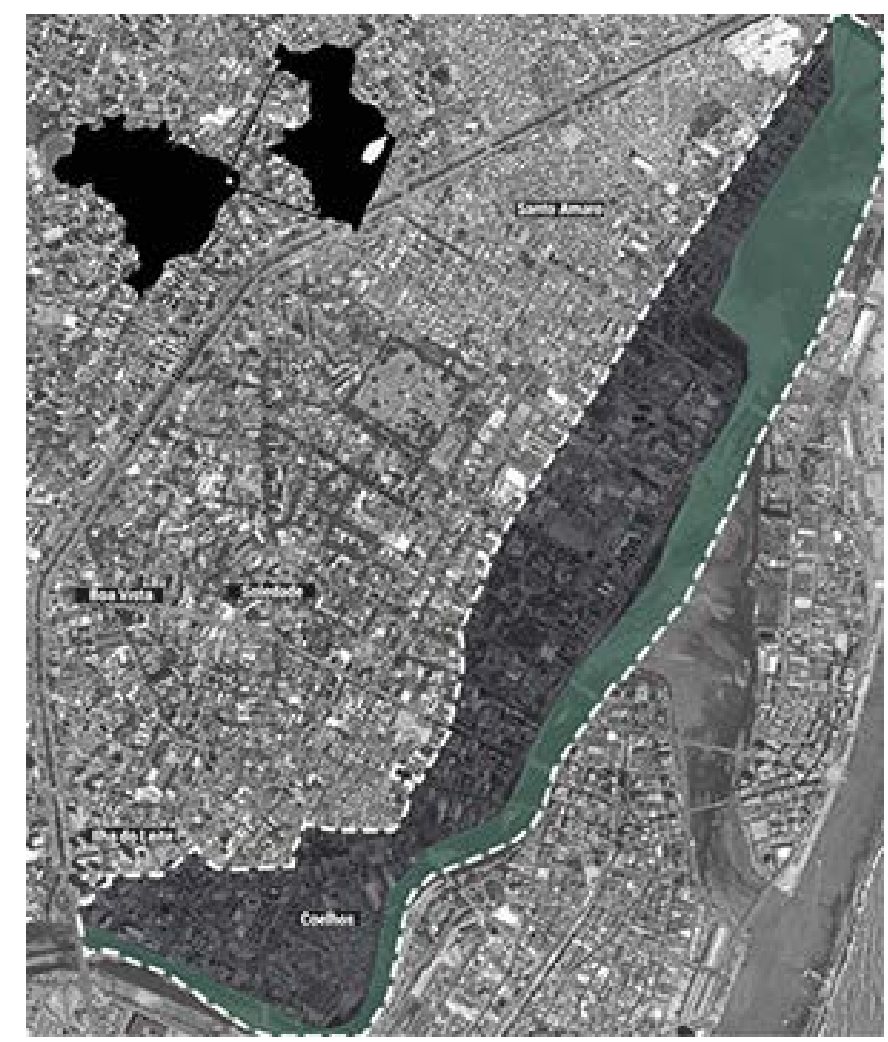

Fig. 4 Localização território de estudo. Elaboração própria a partir de imagem satélite.

O perímetro de estudo abrange parte dos bairros da llha do Leite, Coelhos, Boa Vista e Santo Amaro. Cada um destes, possuem características distintas e papeis fundamentais na evolução histórica da cidade, apresentando edificações significativas, patrimônios históricos e espaços públicos polares na malha urbana. Destacam-se os sobrados da rua da Aurora, a faculdade de Direito do Recife, a sede da Assembleia Legislativa, o Ginásio Pernambucano, o Parque 13 de Maio, o cinema São Luís, entre outros. Além destes, edificações modernistas como o edf. Caête, projetado pelo arquiteto Acácio Gil Borsoi, em 1995. O território conta ainda com praças de variadas dimensões, como por exemplo a Praça Maciel Pinheiro, na Boa Vista, e a praça Miguel de Cervantes, no bairro da llha do Leite. Cabe destacar também as pontes históricas, que também marcaram a evolução da cidade e marcam fortemente até os dias atuais a paisagem urbana do Recife. 


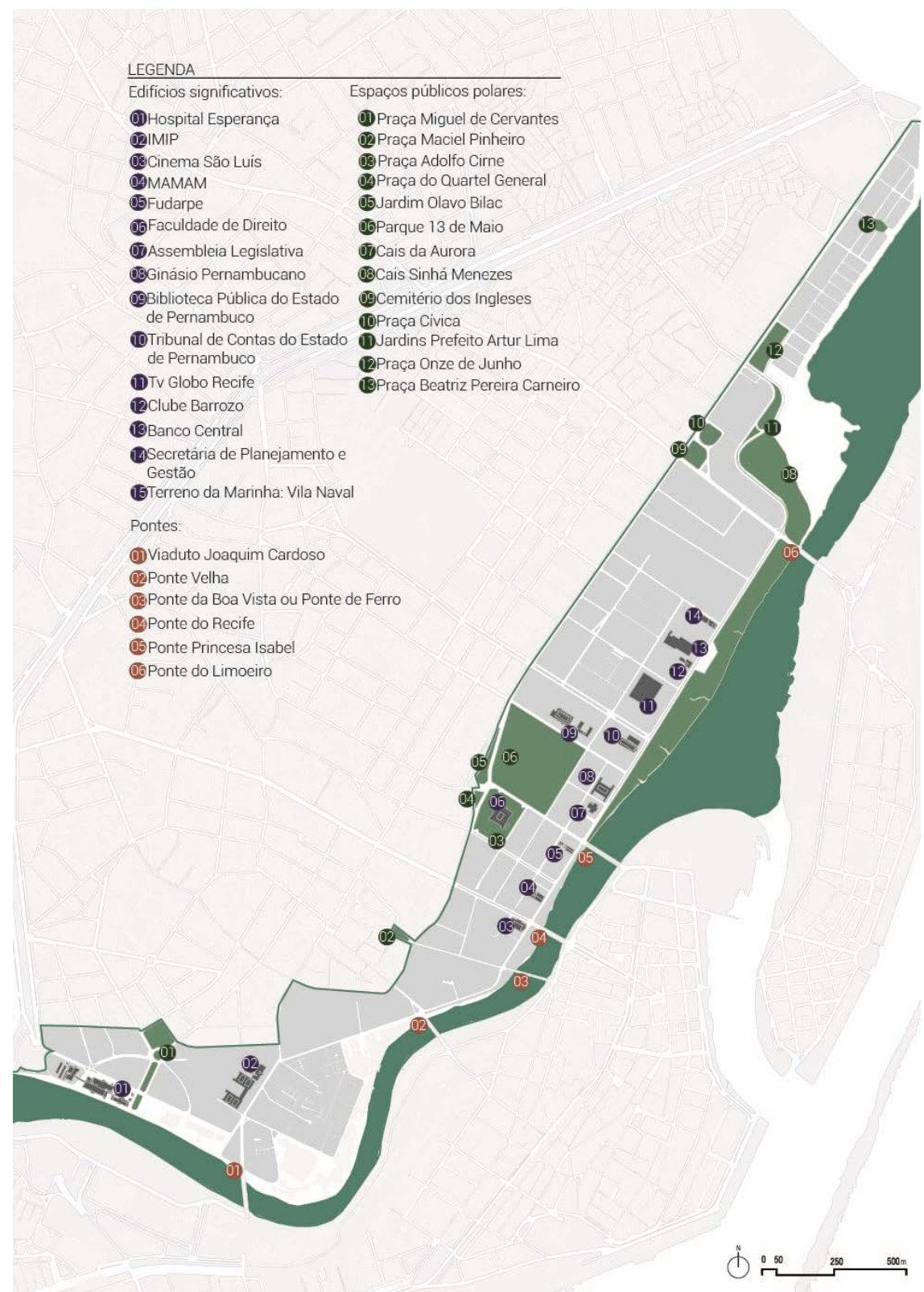

Fig. 5 Mapa de elementos significativos. Elaboração própria a partir de dados do Plano Centro Cidadão (UNICAP/PCR). 


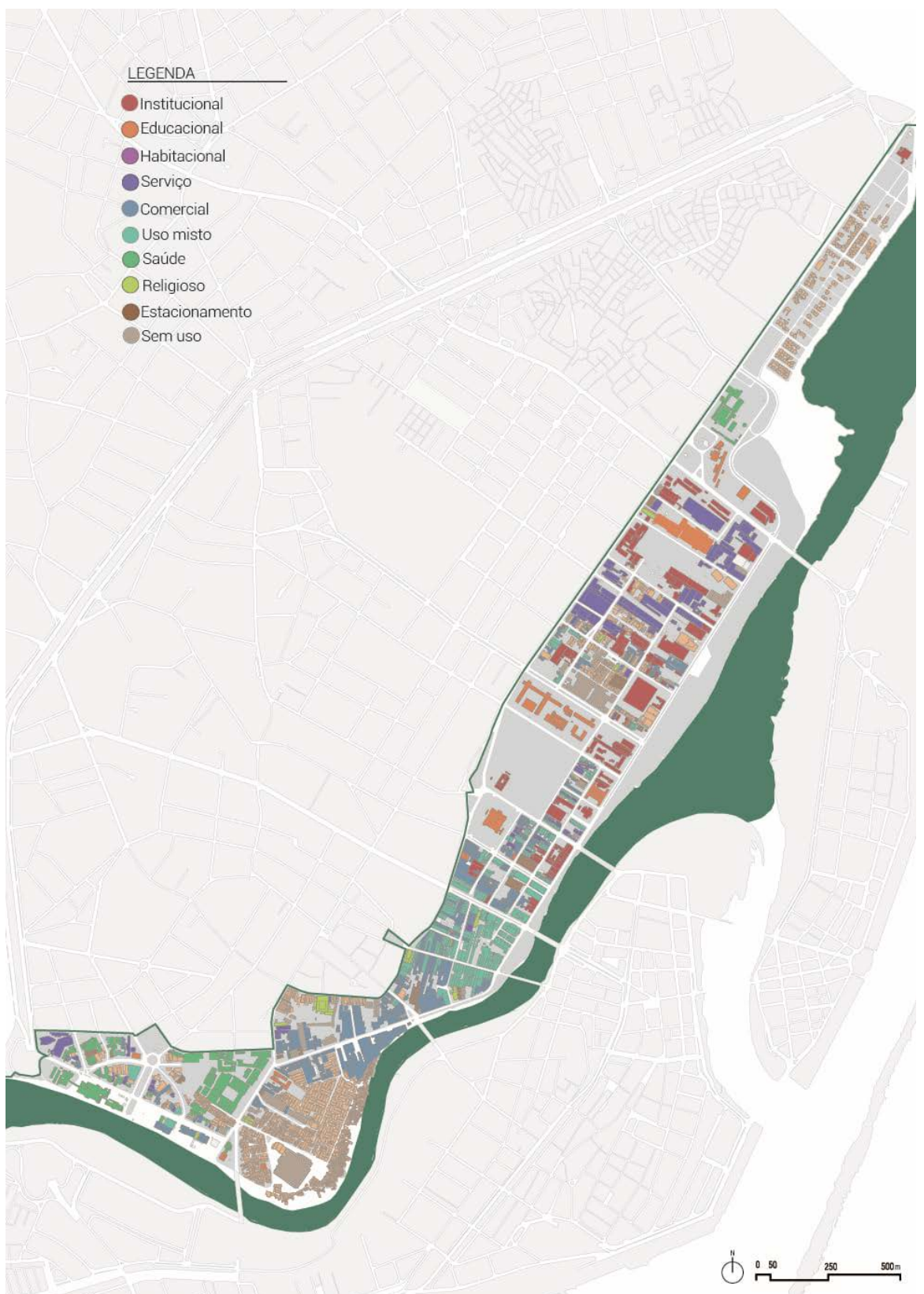

Fig. 6 Mapa de usos. Elaboração própria a partir de dados do Plano Centro Cidadão (UNICAP/PCR).

O território apresenta diversidade de usos, possuindo equipamentos de atividades comerciais, de serviço, institucionais e habitacionais, ainda que estas últimas, apareçam em menor quantidade e focadas em áreas especificas. Assim, a área apresenta grande potencialidade, pois, ao juntar todos os usos, tem-se maior vitalidade urbana. Esse fator faz-se importante para a presente pesquisa, pois os usos influenciam diretamente nos fluxos, tanto de pedestres quanto de veículos. Entretanto, este fator não contribui para a utilização dos espaços públicos presentes, pois estes, não possuem atratividade. Destaca-se também que por conta dos grandes equipamentos presentes no perímetro, o Cais da Aurora possuí atualmente três estacionamentos ao longo de sua área linear, prática que, segundo a organização Project Public Spaces (PPS), ajuda a degradar a longo prazo, o potencial que a frente d'água pode proporcionar. Quase sempre desertas, as praças existentes encontram-se com vegetação e mobiliários degradados, pavimentação deteriorada e precariedade de espaços 
para permanências, contribuindo assim, para que sejam espaços inseguros e abandonados, sem nenhuma atratividade que os torne convidativos para uso da população.

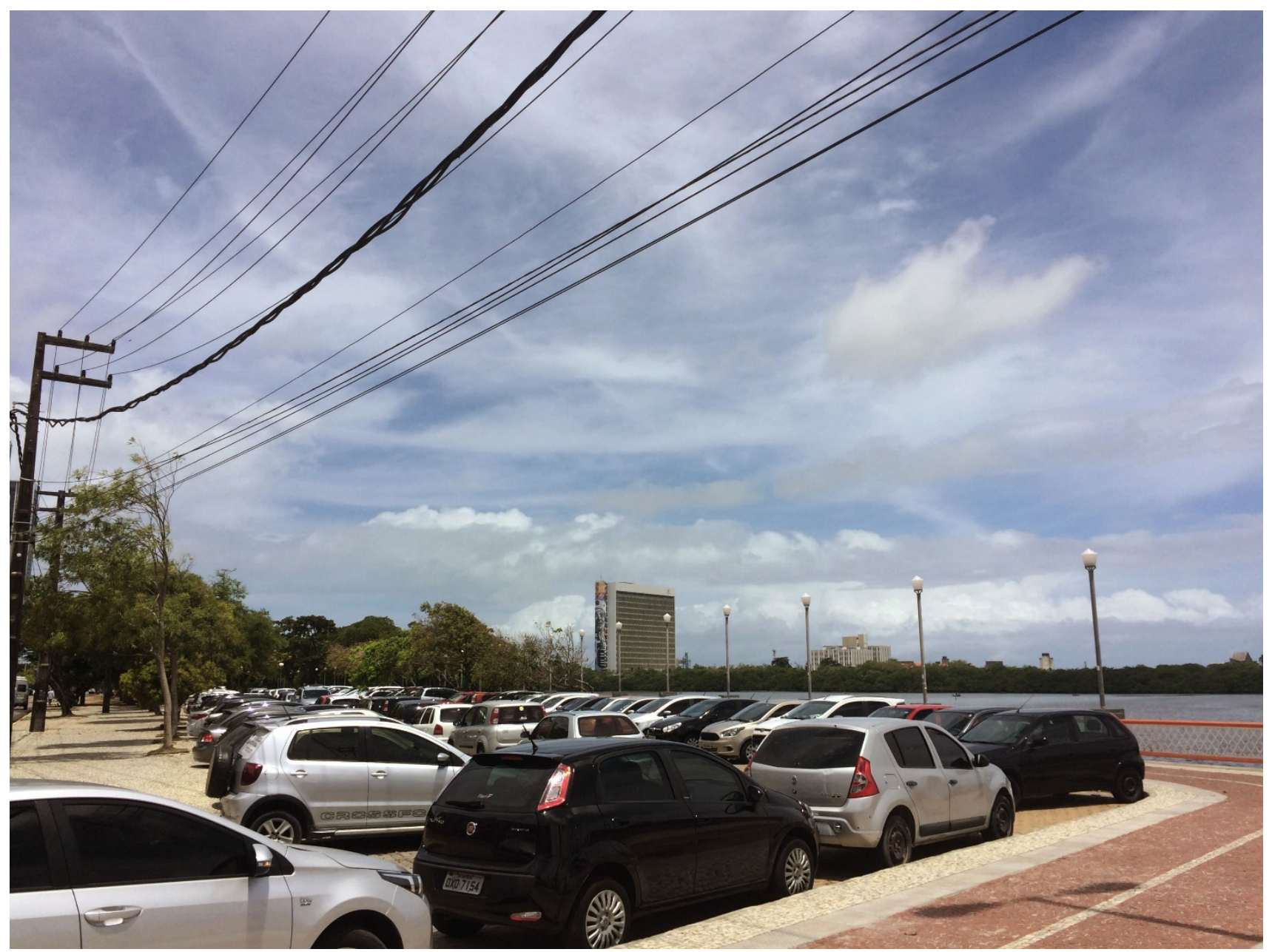

Fig. 7 Registro fotográfico de estacionamento no cais da Aurora. Elaboração própria.

Com objetivo de entender o comportamento da malha urbana e como esta influencia a qualidade de vida na cidade, foram realizadas análises axiais, as quais mostraram que as áreas que apresentam baixos níveis de conectividade e de integração, como é o caso existente nos bairros dos Coelhos e llha do Leite, correspondem às áreas mais insalubres do território. Os assentamentos informais existentes apresentam precárias condições para a qualidade de vida, acarretando uma população menos saudável. 

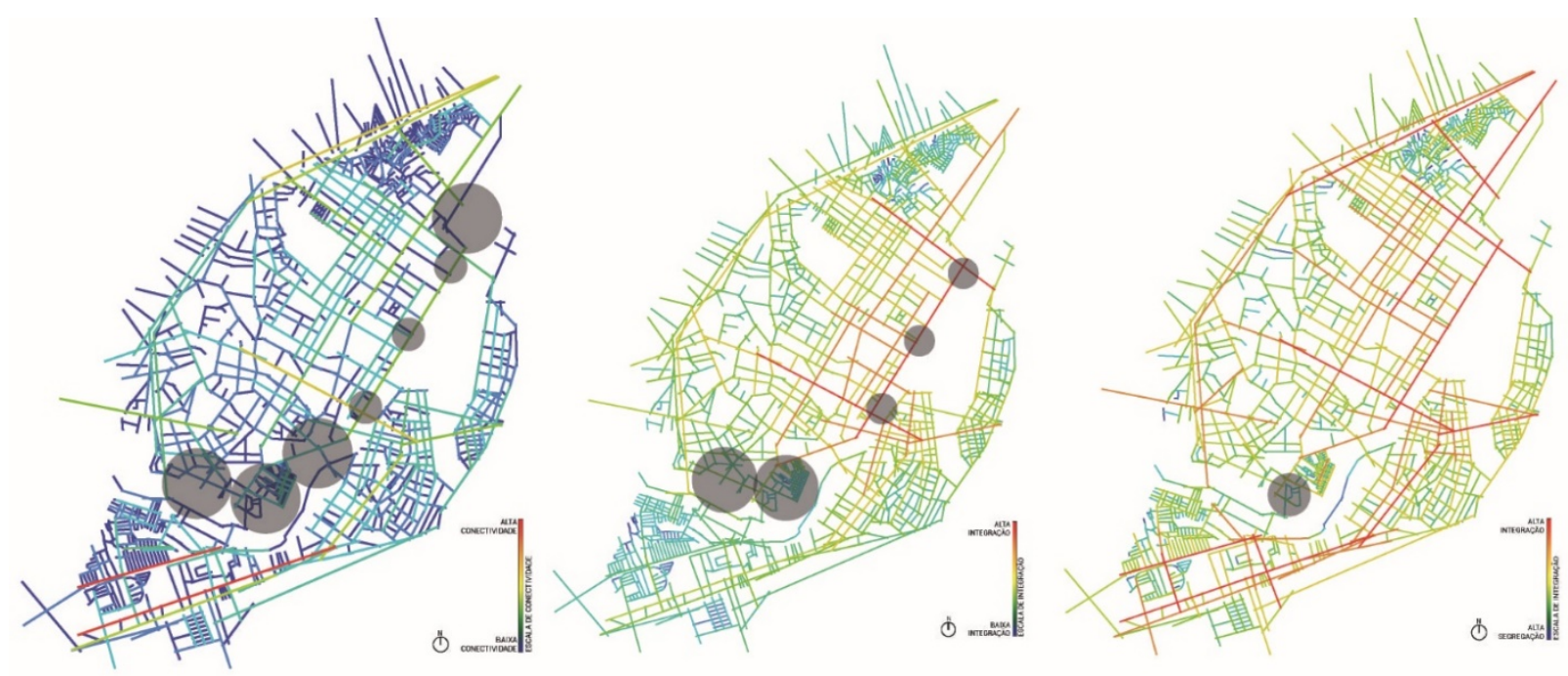

Fig. 8 Mapas axiais de conectividade, integração global e integração local. Elaboração própria a partir de dados do Plano Centro Cidadão (UNICAP/PCR).

Ao cruzar os dados obtidos nos mapas axiais com o comportamento atual dos espaços públicos, nota-se que as áreas mais conectadas e integradas com as demais linhas axiais do sistema urbano, representam as áreas com maiores potenciais para a integração do espaço com a paisagem natural do rio. Este é o caso da rua da Aurora, que segundo mapa de conectividade, articula-se bem na malha urbana da frente d'água e apresenta potencial de centralidade, conforme mostram os mapas de integração. No entanto, isso não quer dizer que o espaço seja bem integrado, já que esta condição não depende apenas da sua configuração na malha urbana.
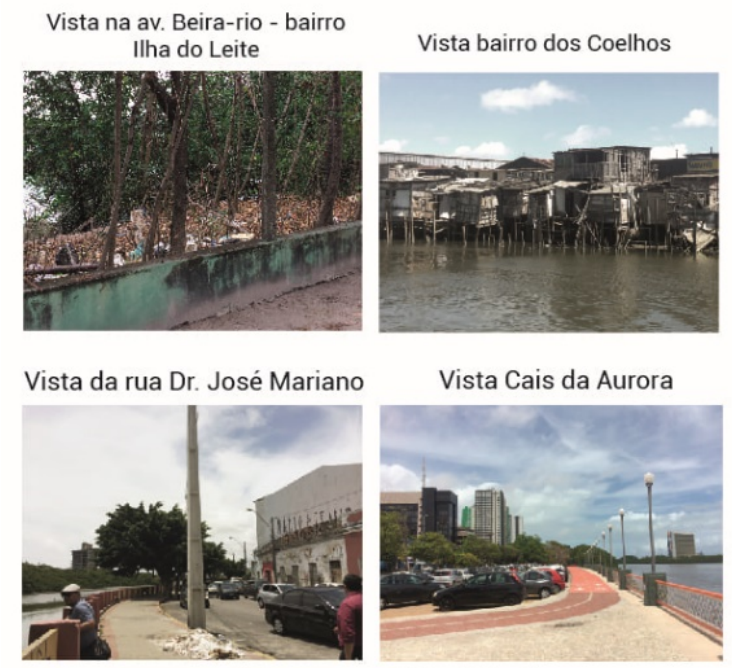

Vista Cais da Aurora

Vista na av. Prefeito Artur Lima Cavalcanti - Cais Sinhá Menezes

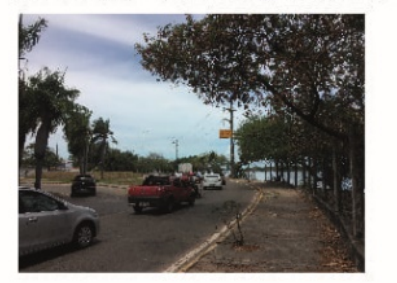

Fig. 9 Registros fotográficos das porções estudadas. Elaboração própria. 
O Cais Sinhá Menezes, corresponde a uma área abandonada, que não promove qualquer interação do usuário com os elementos naturais nela presente, além de não apresentar conforto para o pedestre. O espaço viário da rua da Aurora e da rua Dr. José Mariano, ainda que configure uma boa conectividade com o bairro, apresenta grandes falhas quanto à mobilidade e conforto do pedestre. Os bairros Coelhos e llha do Leite correspondem às porções mais segregadas do território.

O perímetro estudado é intensamente diverso, apresentando características variáveis ao longo de sua extensão. A paisagem, a configuração dos espaços públicos, as edificações construídas em diferentes épocas, a população que vive e trabalha em cada área, tudo isso o torna diverso, com contrastes visuais e físicos, perceptíveis quando percorrido o território sob olhar do rio. No mapa sensitivo abaixo estão algumas das visadas registradas durante passeio de barco e cada uma das áreas marcadas foi associada à uma palavra chave que descreve a paisagem visualizada. A área 1, referente à porção de frente d'água do bairro da llha do Leite, é marcada pela negação da paisagem, onde a margem é negligenciada, servindo de estacionamento de veículos para um equipamento hospitalar existente. Foi observado também muito lixo na beira do rio nesta área, degradando ainda o ecossistema natural. A área 2 é marcada por um grande contraste, percebido assim que se passa pela Ponte Velha, onde surgem as inúmeras palafitas existentes na margem do bairro dos Coelhos e Ilha do Leite. A área 3 representa a rua Dr. José Mariano, com sua série de edificações depredadas, fachadas danificadas que mancham a visada, passando uma sensação de desordem. O Cais da Aurora, área 4, é marcado pela barreira da vegetação que margeia o rio, pois esta, esconde o cais, a rua e as importantes edificações da Aurora. Esse fator é pertinente pois esta vegetação também é uma barreira visual para quem está no cais, diminuindo a integração visual entre as bordas d'água. A área 5 é referente a Av. Prefeito Artur Lima e o Cais Sinhá Menezes, que passa uma sensação de abandono, tanto em terra firme quanto em sua visada para o rio, por não possuir nenhum tipo de integração entre ambiente natural e construído e nenhum tipo de qualidade no espaço público, completamente inseguro para pedestres. Por fim, a área 6 é referente à Vila Naval em Santo Amaro e associa-se à exclusão, pois atualmente, esta área é completamente murada e não possui integração com o entorno.

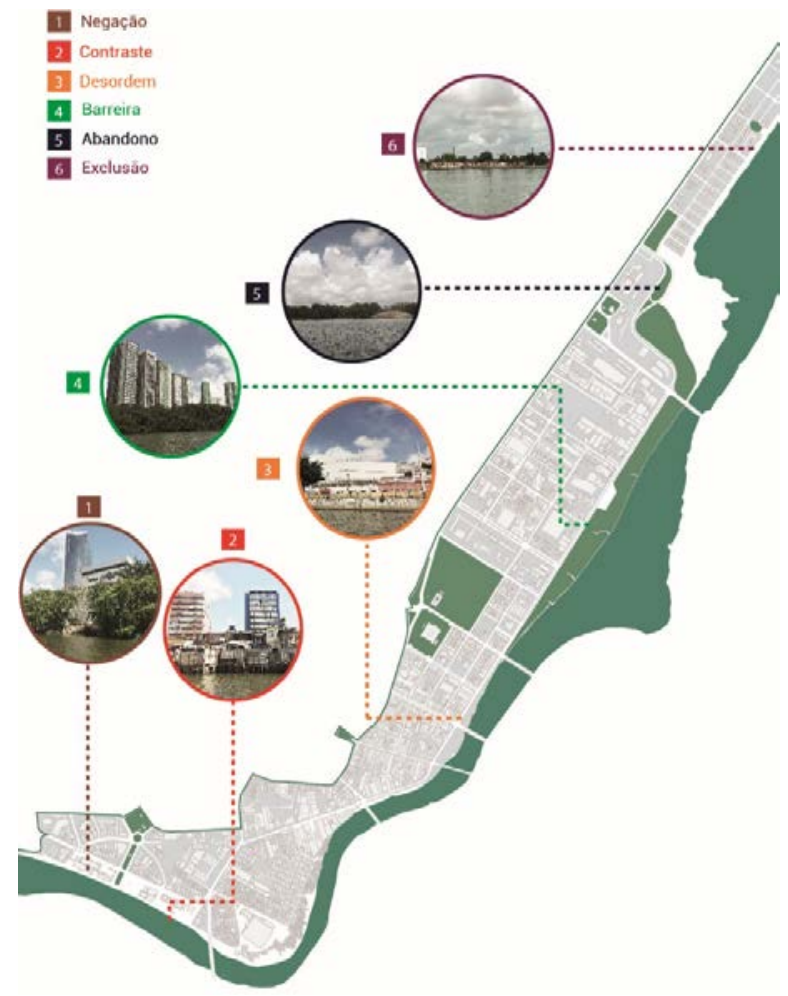

Fig. 10 Configuração da paisagem de frente d'água. Elaboração própria. 

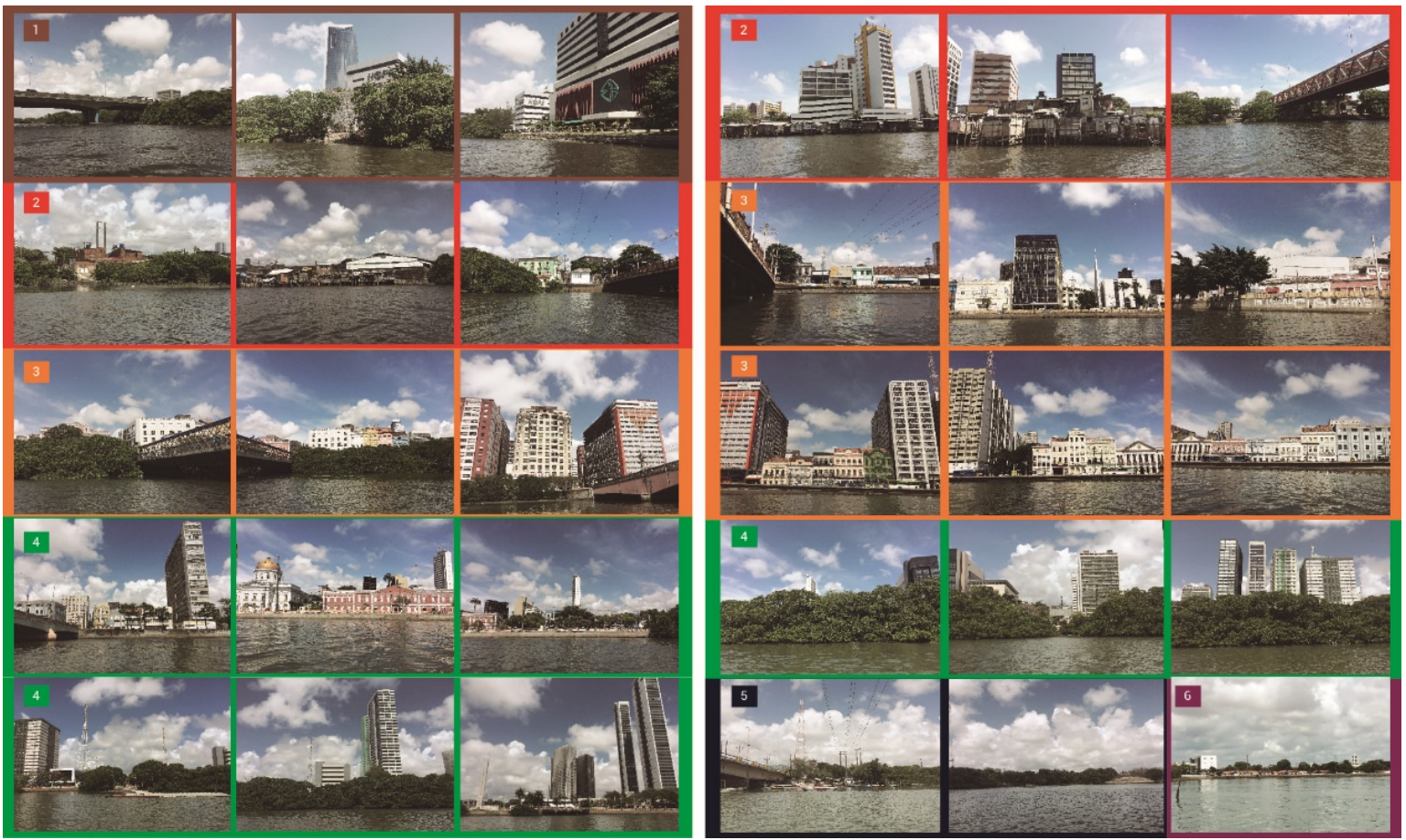

Fig. 11 Diferentes perfis da paisagem de frente d'água. Elaboração própria.

É possível afirmar que, após os estudos realizados, os três principais problemas do espaço público que interferem diretamente na saúde urbana são: falta de integração entre o ambiente construído e o ambiente natural; falta de segurança e conforto para o pedestre; desenho urbano que não favorece o incentivo à diversas atividades físicas e sociais. Com foco nesses problemas foram elaboradas estratégias de desenho urbano com foco no conceito da saúde urbana. Por ser um território extenso e possuir diferentes características ao longo de sua extensão, dividiu-se a área em cinco grandes porções, as quais foram introduzidas diferentes estratégias referentes a cada perfil estudado. 


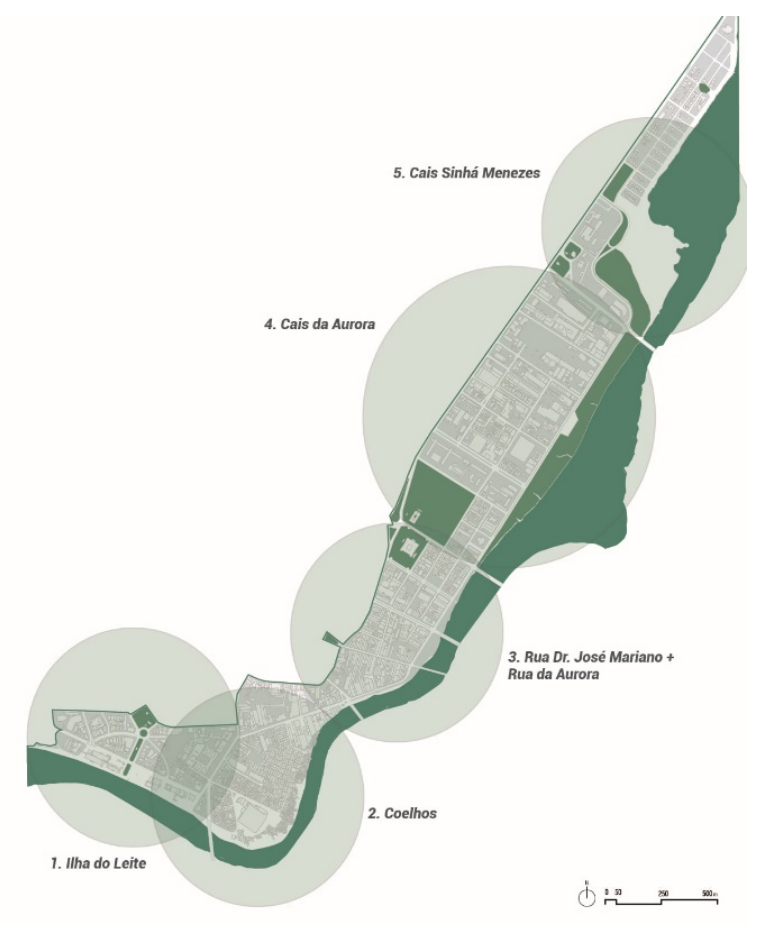

Fig. 12 Divisão das porções no território de estudo. Elaboração própria.

\section{Diretrizes estratégicas:}

De modo geral, uma cidade saudável comporta espaços urbanos de qualidade, com foco no bem-estar e conforto dos usuários, para que dessa forma, cada vez mais, os espaços públicos sejam utilizados, ajudando na prevenção de doenças cardiovasculares, respiratórias e neurológicas. As estratégias visam o incentivo de atividades físicas, a promoção de atividades de lazer, juntamente com melhorias no espaço público viário, o aumento de áreas verdes e a interação dos usuários com todos esses elementos, incluindo o rio. Com base nos estudos aqui apresentados, o design urbano pode abordar três dimensões na promoção da saúde: o bemestar físico, o bem-estar mental e o bem-estar social. Considerando estas três dimensões e seus efeitos, as diretrizes para a cidade saudável baseiam-se em um design que promova o bem-estar geral, com foco nas particularidades de cada área e de seus usuários.

\subsection{Estratégias:}

Como colocado anteriormente, para cada um dos três níveis de bem-estar, foram identificadas as chamadas "ambições". Estas, traduzem de forma objetiva os atributos necessários para obtenção de cidades mais saudáveis. Após entendimento das necessidades locais da área aqui apresentada, foram elaboradas diretrizes em formato de estratégias de melhoria, focadas nas ambições previamente apresentadas. As estratégias se apresentam com base nos problemas existentes, os quais podem ser encontrados em diversos e distintos lugares, tornando-as aplicáveis universalmente, servindo não apenas para o território aqui estudado e apresentado, mas sim podendo ser aplicadas em cidades de diferentes configurações e escalas, já que sintetizam de forma universal, os atributos necessários para cidades mais saudáveis. 


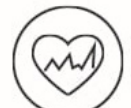

BEM ESTAR FÍSICO:

espaço urbano caminhável

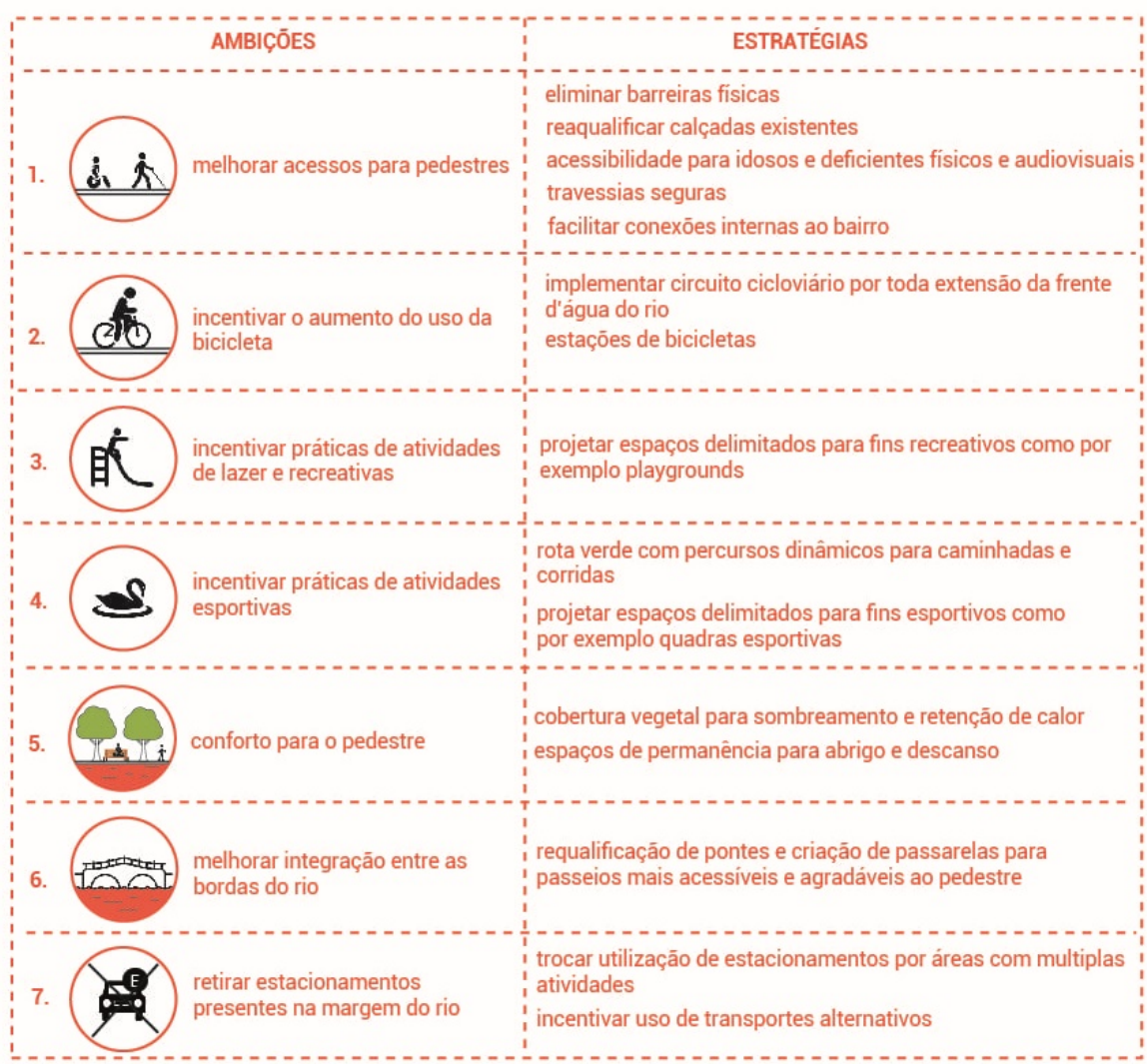

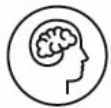

BEM ESTAR MENTAL:

espaço urbano com

restaurador mental

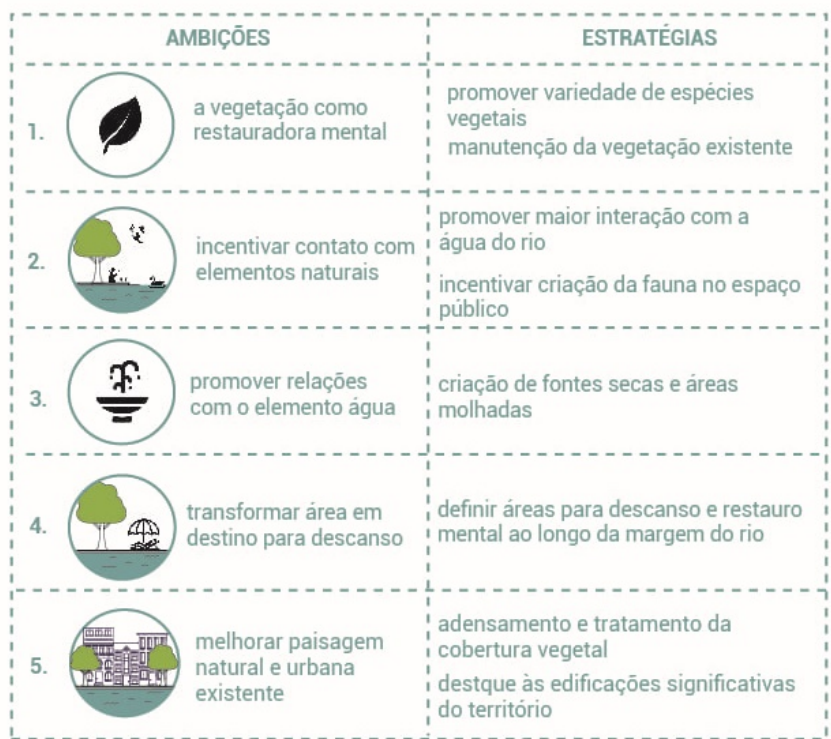

BEM ESTAR SOCIAL:

espaço urbano como estruturado de relaçōes sociais

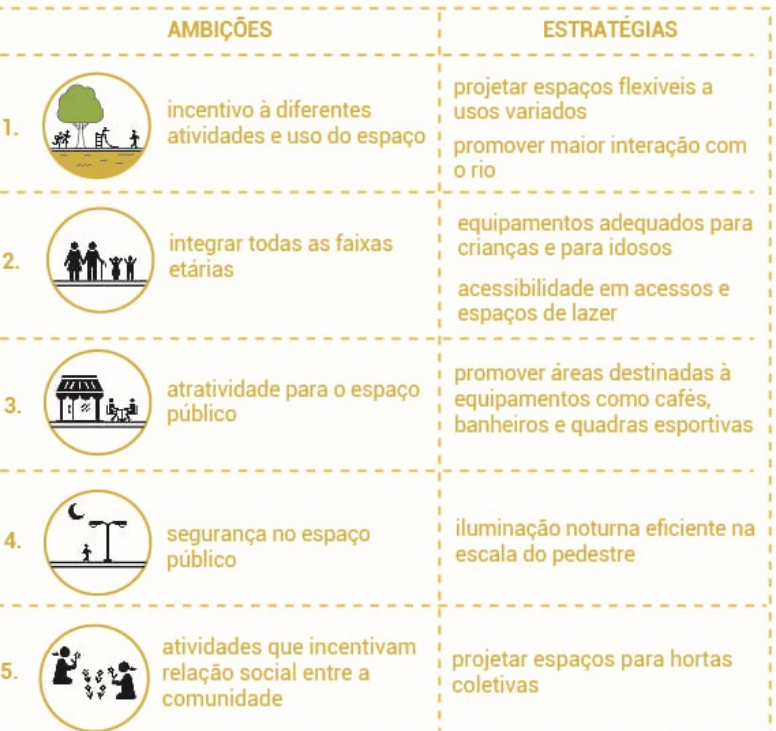

Fig. 13 Diretrizes elaboradas: bem-estar físico, mental e social. Elaboração própria. 


\subsection{Intervenções:}

Conforme resultados obtidos no diagnóstico urbano, que demonstrou as variações existentes ao longo do território, a divisão deste em 5 porções distintas possibilitou uma medição mais aprofundada das necessidades de cada área, para, portanto, apresentar intervenções assertivas.

\subsubsection{Porção Ilha do Leite:}

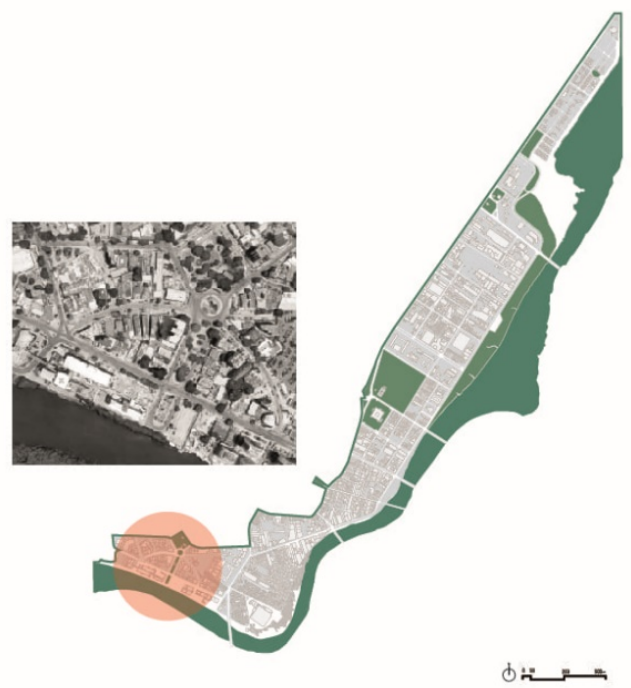

Fig. 14 Localização da porção Ilha do Leite. Elaboração própria.

Esta porção do território corresponde à frente d'água do bairro da llha do Leite. Assim como no bairro dos Coelhos, há uma grande quantidade de habitações informais em palafitas ao longo da margem. A partir de políticas habitacionais eficazes, as famílias devem ser relocadas para habitações multifamiliares com melhores condições. Com base nas estratégias estabelecidas, as intervenções para esta porção são: requalificação dos espaços verdes existentes e inserção de novos espaços verdes, retirada de estacionamento na margem e implantação de ciclofaixa para fechar um circuito cicloviário por toda a frente d'água, construção de piers que poderão incentivar o bem-estar mental e social, através do contato com a natureza existente. A Praça Miguel de Cervantes deve ser requalificada, contando com espaços flexíveis a diferentes tipos de interações e atividades, tais como áreas para crianças, hortas comunitárias, lagos e fontes secas, áreas de descanso, rotas dinâmicas. 


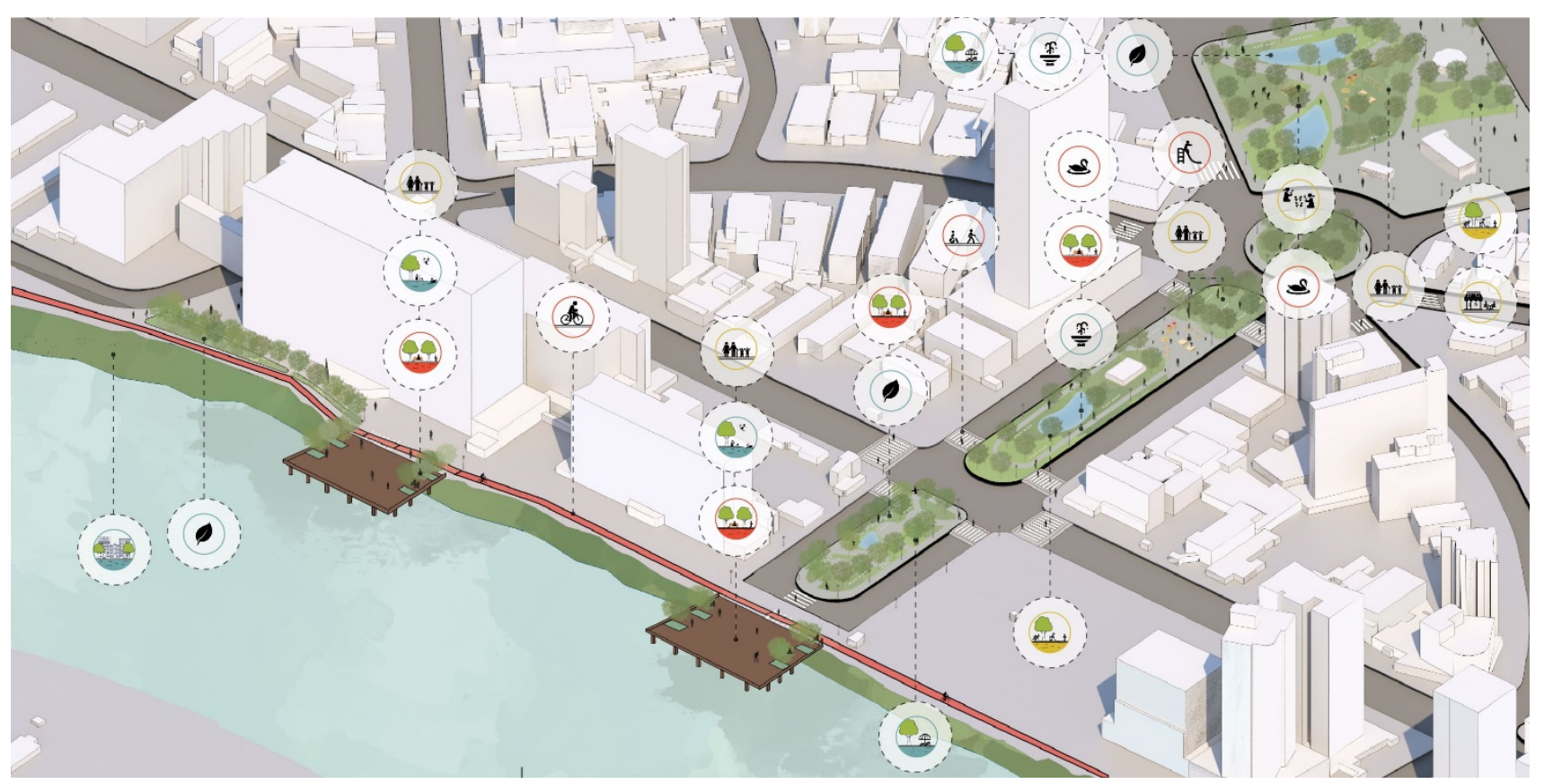

Fig. 15 Intervenções e diretrizes ilustradas para porção Ilha do Leite. Elaboração própria.

\subsubsection{Porção Coelhos:}

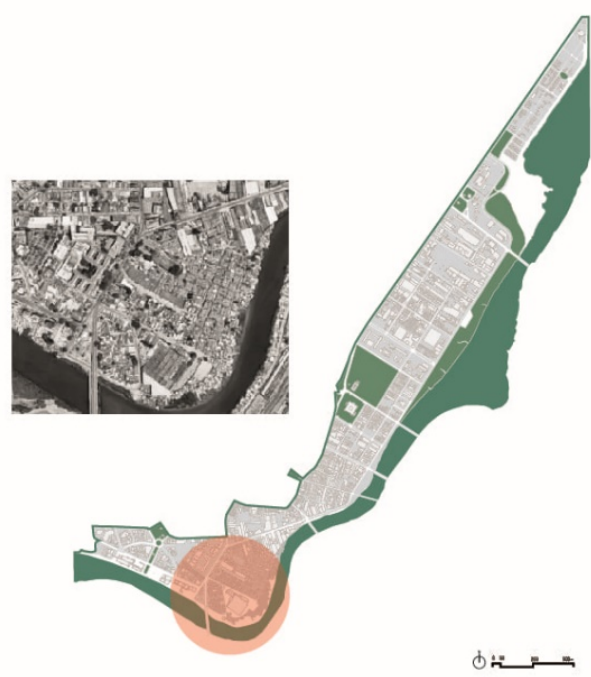

Fig. 16 Localização da porção bairro dos Coelhos. Elaboração própria.

Ainda mais do que na llha do Leite, a frente d'água no bairro dos Coelhos apresenta uma grande quantidade de moradias informais e insalubres. Considerando a retirada das palafitas e a mudança das famílias ribeirinhas para melhores habitações e com base nas estratégias estabelecidas, as intervenções para esta porção têm foco na requalificação da margem para promover conforto e atividades diferenciadas para moradores da comunidade ZEIS (Zona Especial de Interesse Social) existente. Estas melhorias incluem: áreas verdes com espaços flexíveis para abrigar atividades que integrem todas as faixas etárias, nova ciclofaixa para circuito cicloviário, rotas dinâmicas para prática de exercícios físicos e hortas comunitárias. Como intervenção tem-se 
também a transformação de um trecho da Av. Beira Rio em uma via compartilhada, onde um platô eleva a via e a torna confortável ao pedestre, possibilitando novas oportunidades de lazer e interação para as crianças que frequentam a escola ali presente.

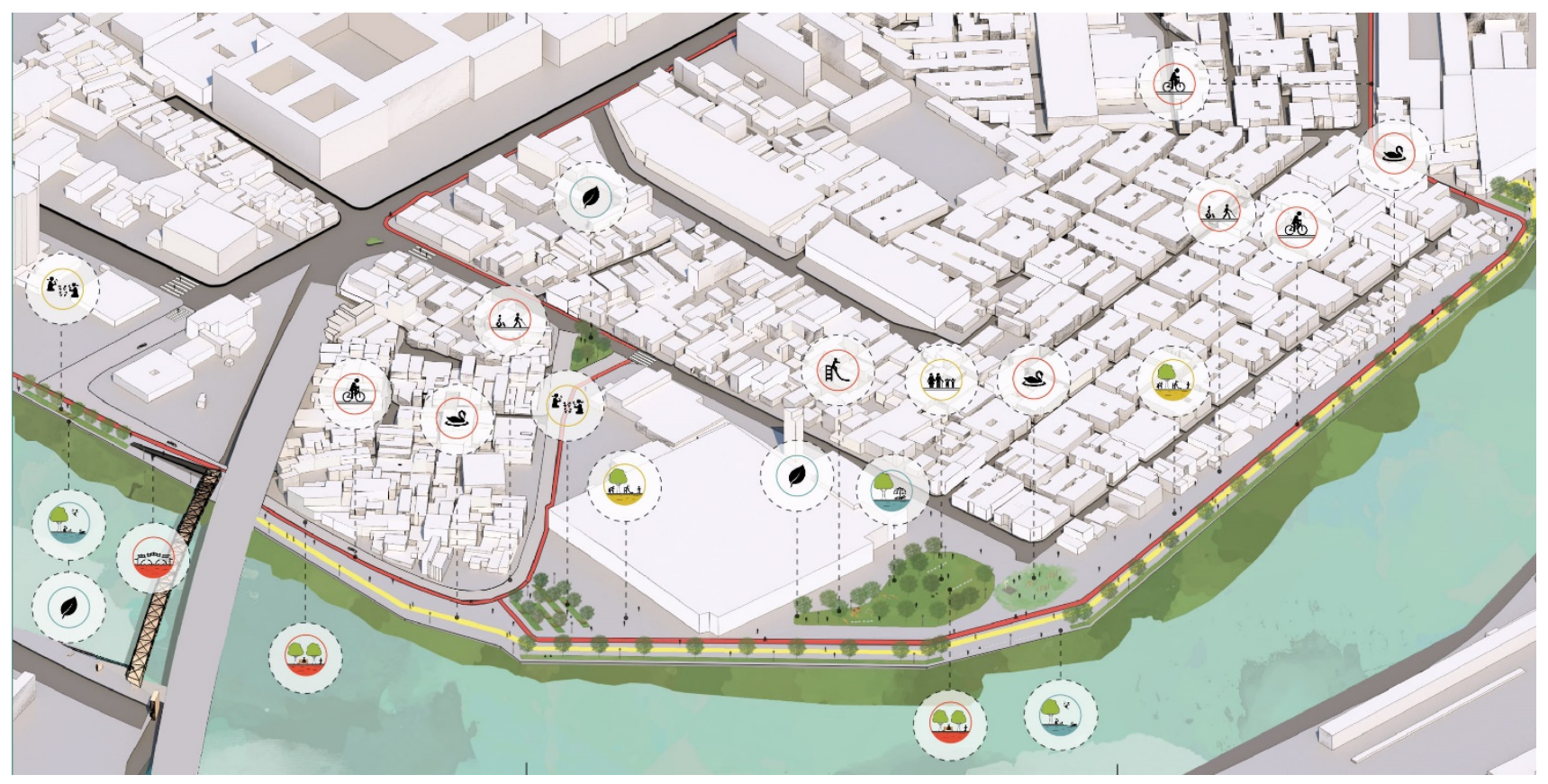

Fig. 17 Intervenções e diretrizes ilustradas para porção bairro dos Coelhos. Elaboração própria.

\subsubsection{Porção Rua Dr. José Mariano e Rua da Aurora:}

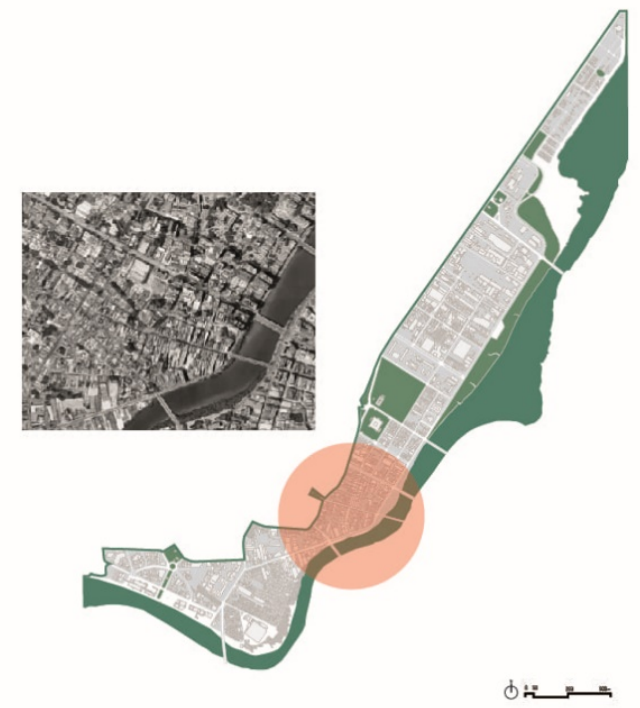

Fig. 18 Localização da porção rua Dr. José Mariano e rua da Aurora. Elaboração própria. 
Esta porção representa a rua Dr. José Mariano e uma parte da rua da Aurora. Possui, como maior desafio, a inclusão do pedestre na movimentada via. Com base nas estratégias estabelecidas, as intervenções para esta porção são: retirada de uma faixa de estacionamento existente para dar continuidade ao circuito cicloviário, além disso, em alguns momentos, o aumento da calçada, para promover mais conforto ao pedestre, novas faixas para travessias mais seguras, manutenção da pavimentação das calçadas, além do melhoramento da vegetação existente com a manutenção dos canteiros e plantio de novas árvores.

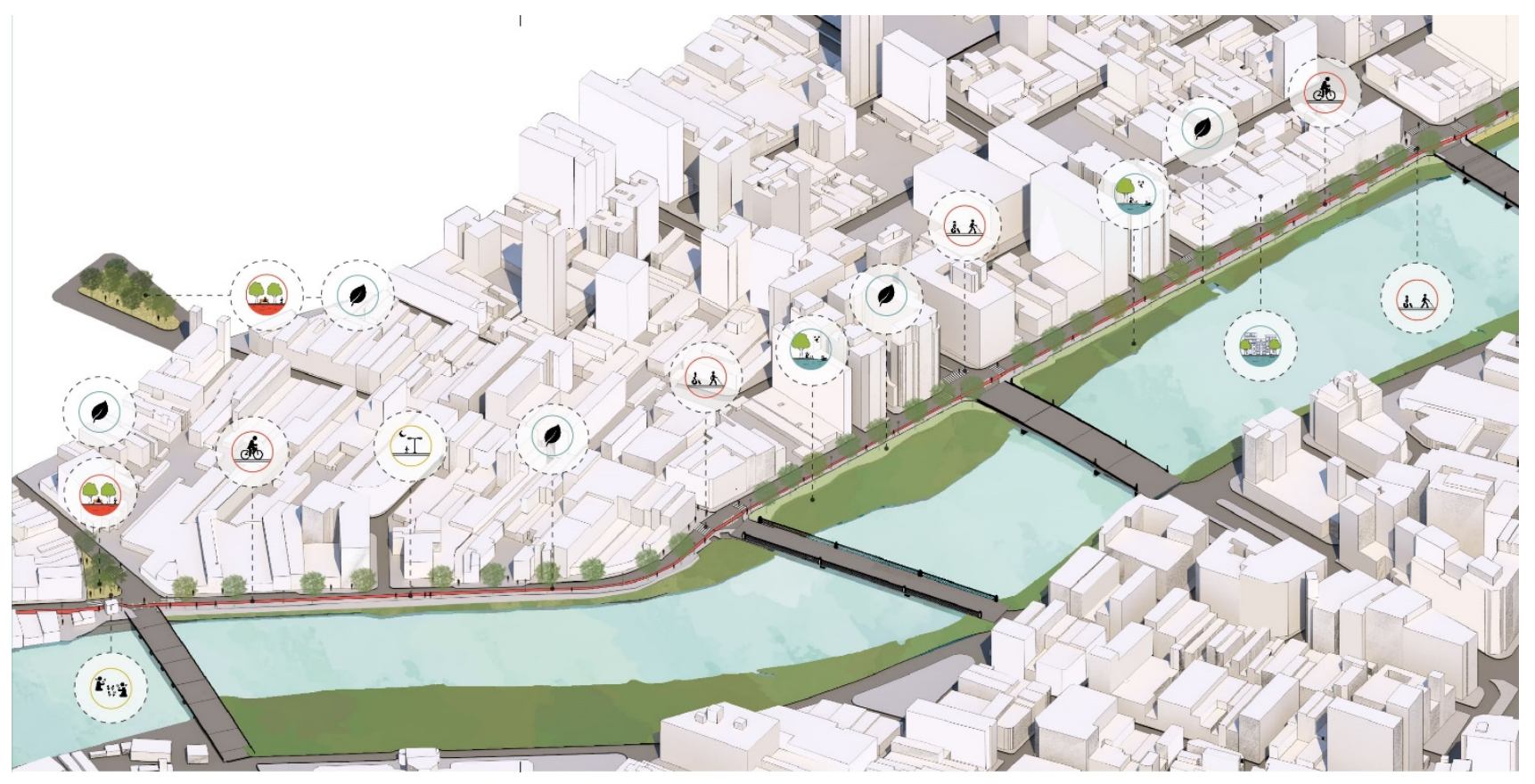

Fig. 19 Intervenções e diretrizes ilustradas para porção rua Dr. José Mariano e rua da Aurora. Elaboração própria

\subsubsection{Porção Cais da Aurora:}

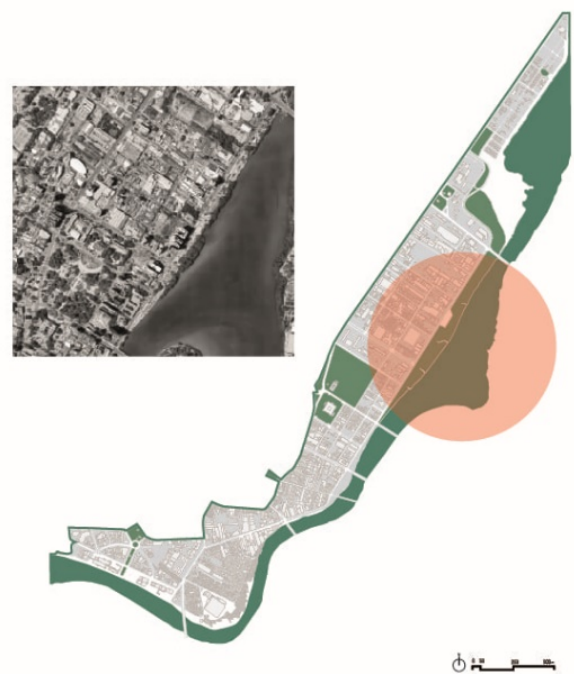

Fig. 20 Localização da porção cais da Aurora. Elaboração própria. 
A porção do Cais da Aurora já apresenta algumas estratégias estabelecidas, como por exemplo a ciclofaixa existente e alguns equipamentos esportivos. Entretanto, grande parte destes equipamentos não possuem bom estado de conservação. Portanto, o foco é o aproveitamento da extensa área linear para incluir novas estratégias que promoverão maiores índices de bem-estar. Com base nas estratégias estabelecidas, as intervenções são: áreas para atividades recreativas e esportivas como quadras e rotas dinâmicas para prática de exercícios, novas áreas verdes, com cobertura vegetal e espaços para descanso, espaços flexíveis para diferentes tipos de atividades e faixas etárias, hortas comunitárias e espaços livres para promoção de eventos, além de equipamentos atrativos como lojas e cafés, e banheiros públicos. $O$ trecho também deve contar com um pier para observação, contemplação, descanso e local de encontro entre pessoas.

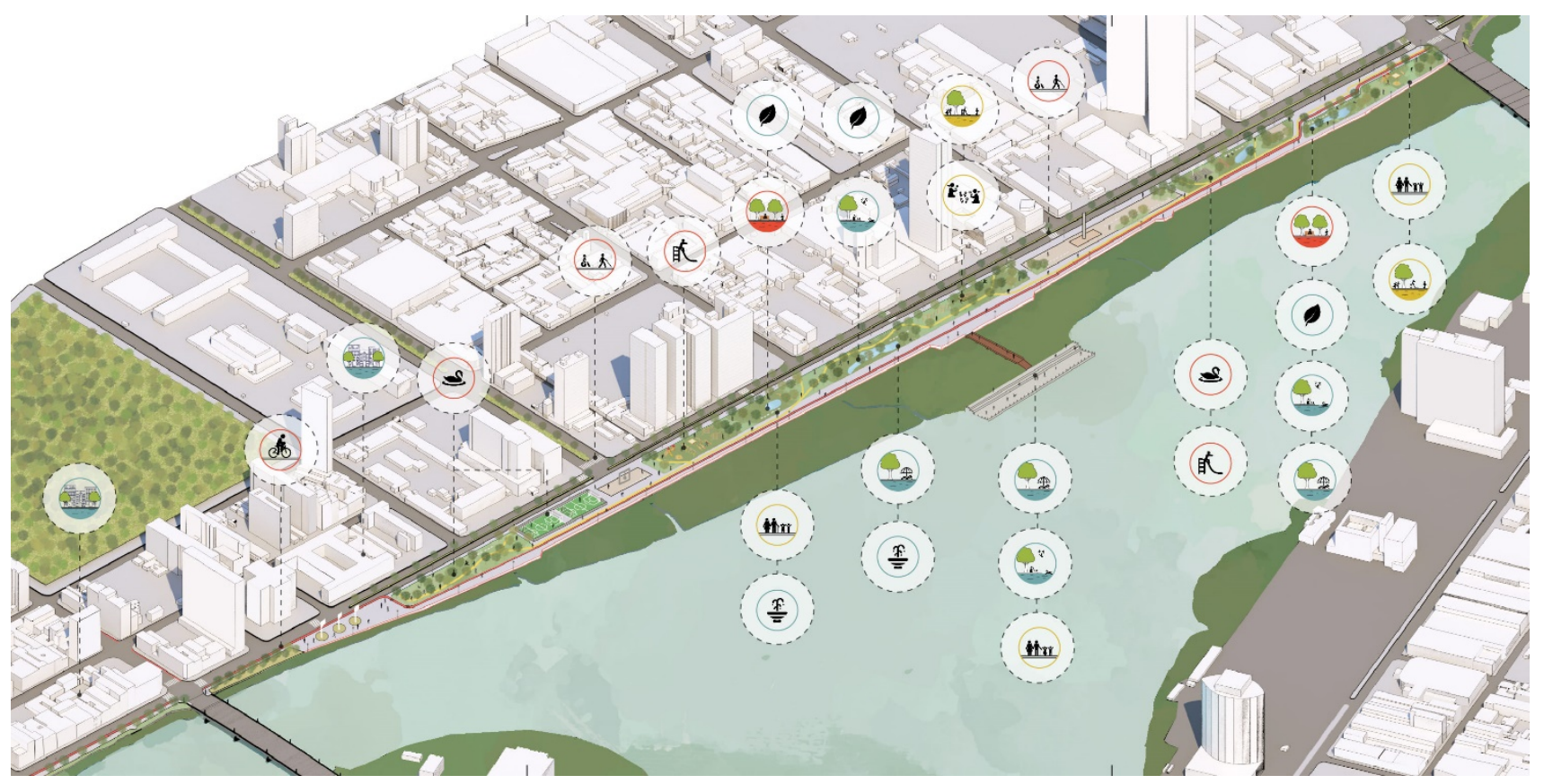

Fig. 21 Intervenções e diretrizes ilustradas para porção Cais da Aurora. Elaboração própria.

\subsubsection{Porção Cais Sinhá Menezes:}

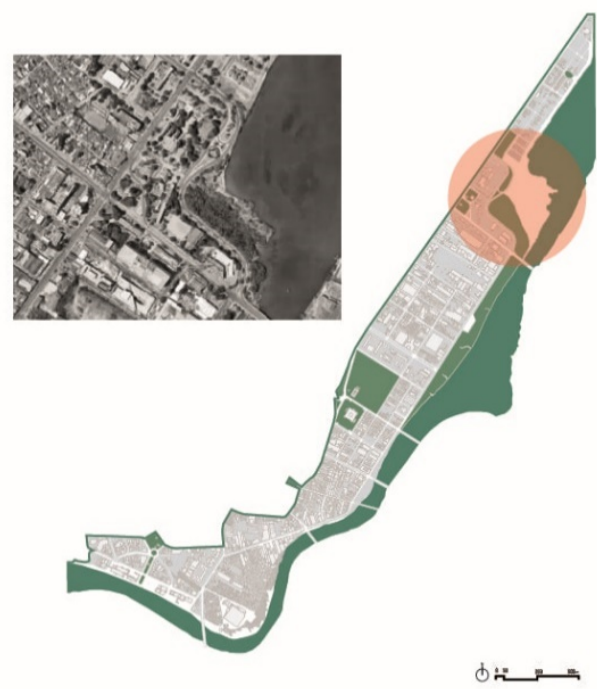

Fig. 22 Localização da porção Cais Sinhá Menezes. Elaboração própria 
A porção do Cais Sinhá Menezes possui como maior desafio a Av. Prefeito Artur Lima Cavalcanti, que não apresenta conforto e segurança ao pedestre. Neste trecho, a margem do rio apresenta extensa vegetação de mangue, que encontra-se poluída, impossibilitando-a de promover sua fauna, tornando-a um elemento indesejado. Com base nas estratégias estabelecidas, as intervenções para esta porção são focadas no conforto para o pedestre e na preservação do ecossistema, através de: inserção de faixas para pedestres ao longo da avenida, assim como iluminação apropriada para segurança noturna, alargamento de calçadas, requalificação das áreas verdes através da manutenção da vegetação existente, criação de áreas para descanso com cobertura vegetal e locação de piers para interação com elementos naturais, que também promoverá apoio aos pescadores que por ali atracam seus barcos. A porção já apresenta ciclofaixa instalada, aumentando seu potencial para cumprir com as ambições necessária.

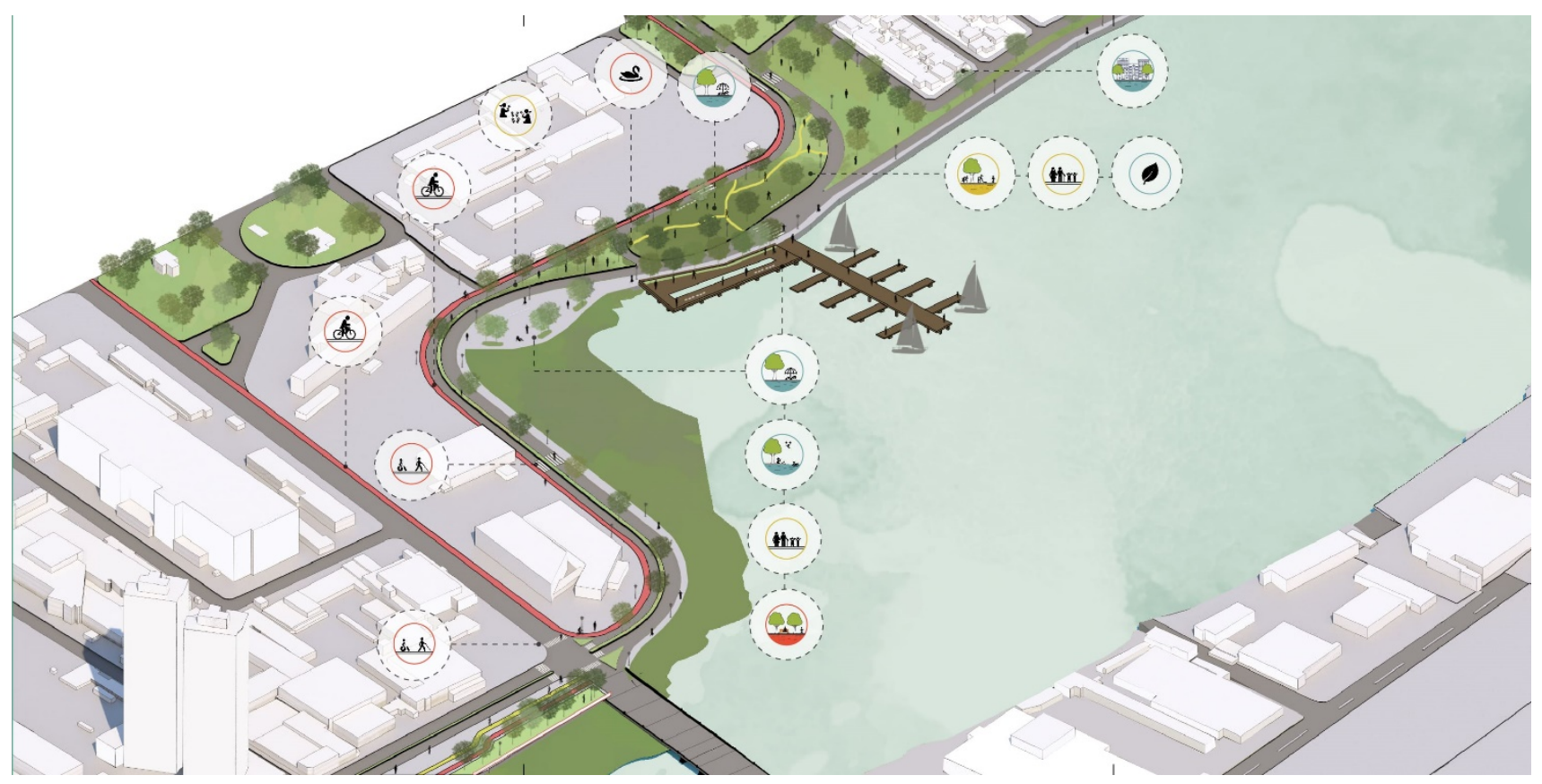

Fig. 23 Intervenções e diretrizes ilustradas para porção Cais Sinhá Menezes. Elaboração própria.

\section{Considerações Finais:}

O campo da saúde urbana é extenso, e nesta pesquisa foi abordada a questão de como nossa saúde pode ser influenciada pelas cidades onde vivemos. Através dos espaços abertos é possível diminuir níveis de estresse e consequentemente melhorar a saúde da população, já que estes podem incentivar a prática de atividades físicas e sociais, ajudando na diminuição de casos de doenças cardiológicas, respiratórias e neurológicas. Para garantir isso, é necessário que estes espaços sejam adequados com base no que diz o conceito da saúde urbana, que fundamentou esta pesquisa.

Ao compreender que as frentes d'água são territórios de grande potencialidade para a saúde urbana das cidades, o objetivo da presente investigação foi realizar um diagnóstico e propor diretrizes e estratégias de desenho urbano para a frente d'água do Centro Expandido Continental do Recife. Verificou-se a importância deste espaço tanto em termos históricos, quanto em termos de configuração na malha urbana, como também 
o grande potencial, mas que atualmente não apresenta o conjunto de características necessárias para atingir os níveis de bem-estar.

A abordagem aqui aplicada em um território específico, pode também ser replicada à outros territórios e espaços urbanos. As diretrizes apresentadas cumprem com a função de tornar a cidade saudável algo mais próximo para qualquer escala de território, uma vez que, as estratégias estudadas já vêm sendo aplicadas em outras cidades ao redor do mundo. Entretanto, uma cidade saudável não será atingida apenas com a utilização de uma ou duas estratégias, e sim a partir do entendimento que todas se relacionam e articulam as melhorias em espaços públicos. Além do incentivo à uma população mais saudável, pensar a cidade com foco na saúde urbana também adiciona benefícios sociais, econômicos, políticos, ambientais e culturais às cidades.

O estudo dos espaços públicos torna-se essencial atualmente, em que as cidades estão cada vez mais densas. A maneira como planejamos a cidade transforma a forma como vivemos e por isso este processo de estudo, aferição e proposição em busca de melhores condições para espaços urbanos deve estar sempre em evidência no planejamento de todas as cidades. As novas políticas urbanas, os novos planos e projetos devem priorizar e prezar pela qualidade do espaço público, para que as cidades possam colaborar com um estilo de vida mais sustentável e contemporâneo onde a vida urbana é mais ativa, mais confortável, segura e mais saudável.

\section{BIBLIOGRAFIA}

ASENSIO VILLORIA, L., MAH, D. (2016). Lifestyled: Health and Places. Berlin: Jovis VerlagGmbH.

ABRAHAM, A. et al. (2009). Landscape and well-being: a scoping study on the health promoting impact on outdoor environments. Internacional Journal of Public Health. Site: https://www.researchgate.net/publication/26825808_Landscape_and_well-being_A_ scoping_study_on_the_health-promoting_impact_of_outdoor_environments (Consulta:27/08/2017). FARR, D. (2013). Urbanismo Sustentável: desenho urbano com a natureza. Porto Alegre: Bookman.

GALEA, S., VLAHOV, D. (2005). The Handbook of Public Health: populations, methods and practice. Nova lorque: Springer Science + Business Media Inc.

GEHL, J. (2013). Cidades Para Pessoas. São Paulo: Perspectiva.

HILLIER, B., HANSON, J. (1984). The social logic of space. London: Cambridge University Press.

LEFEBVRE, H. (2001). O direito à cidade (143 p). São Paulo: Centauro.

LEITE, C. (2012). Cidades sustentáveis, cidades inteligentes: desenvolvimento sustentável num planeta urbano. São Paulo: Grupo A Educação S.A.

MCHARG, I. (1992). Design with Nature. New York: John Wiley \& Sons, Inc.

MENEZES, P., CARNEIRO, A. (2014). Uma Compreensão Sistémica da Paisagem do Recife: Ordenamento da Paisagem através dos Corpos de água. 3o Colóquio Ibero- Americano: paisagem cultural, patrimônio e projeto. Belo Horizonte. Site: http://www.forumpatrimonio.com.br/paisagem2014/artigos/pdf/284.pdf (Consulta: 12/09/2017).

KAPLAN, R, KAPLAN S. (1989). The experience of nature: a psychological perspective. Cambridge University Press, Cambridge. Site: http://willsull.net/resources/270-Readings/ExpNature1to5.pdf (Consulta: 17/10/2017).

ROE, J. (2016). Cities, Space and Mental Well-Being. Environment and Human Health, Environmental Sociology and Psychology. Oxford Research Encyclopedia of Environmental. Site: 
http://environmentalscience.oxfordre.com/view/10.1093/acrefore/9780199389414.001.0001/acrefore9780199 389414-e-93?print=pdf (Consulta: 01/09/2017)

ROE, J. et al. (2013). Green Space and Stress: Evidence from Cortisol Measures in Deprived Urban Communities. Int J Environ Res Public Health. Site: https://www.ncbi.nlm.nih.gov/pmc/articles/PMC3799530/ (Consulta: 02/11/2017).

RYDIN, Y. et al. (2012). Shaping cities for health: complexity and the planning of urban environments in the 21st century. Site: https://www.ncbi.nlm.nih.gov/pmc/articles/PMC3428861/ (Consulta: 20/08/2017).

SILVA MACIEL, P. et al. (2018) Diagnóstico urbanístico para o Centro Expandido do Recife. Recife: UNICAP. WORLD HEALTH ORGANIZATION. (2016). Urban green spaces and health: a review of evidence. Copenhagen. Site: http://www.euro.who.int/_data/assets/pdf_file/0005/321971/Urban-green-spaces-andhealth-review-evidence.pdf?ua=1. (Consulta: 30/082017). 